\title{
Steroid sensitive systemic disease with anaemia in the elderly: a manifestation of giant cell arteritis?
}

\author{
M.C. Allison* and K.R. Gough \\ Royal United Hospital, Combe Park, Bath, BA1 3NG, UK.
}

\begin{abstract}
Summary: Nine elderly patients presented with features of a multisystem disorder thought to be either a connective tissue disease of undefined type or disseminated malignancy. Associated features were a normochromic anaemia, raised erythrocyte sedimentation rate (ESR) (or plasma viscosity) and raised serum alkaline phosphatase levels. None had symptoms to suggest either giant cell arteritis or polymyalgia rheumatica. Temporal artery biopsy was performed before trial of corticosteroid therapy in four, and two showed giant cell arteritis. All nine responded dramatically to corticosteroids and the anaemias resolved. One died after $6 y$, and the rest are well after 1 to $7 y$.
\end{abstract}

\section{Introduction}

We set out to review our recent experience in managing 9 elderly patients with a variety of constitutional symptoms, such as anorexia, weight loss, lassitude and pyrexia up to $38^{\circ} \mathrm{C}$, all of whom were found to have a considerably raised plasma viscosity and a normochromic or slightly hypochromic anaemia. Detailed investigations failed to define the cause in all but 2 patients. These were found to have biopsy proven giant cell arteritis (GCA). We treated all 9 with steroids on the presumption that those without a firm diagnosis had an 'occult' arteritis. We carefully sought objective evidence of improvement by monitoring laboratory data.

\section{Patients and methods}

Case notes were sought on all former inpatients who had an unexplained normochromic anaemia associated with severe systemic symptoms, and in whom no initial diagnosis was made despite extensive tests.

Nine cases were identified under the care of one physician (KRG). There were 5 women and 4 men and the age range at presentation was $60-77 \mathrm{y}$. None had the classical symptoms of GCA or polymyalgia rheumatica. Their presenting symptoms and laboratory data are outlined in Table I.

Correspondence: M.C. Allison, M.B., M.R.C.P.

* Present address: Academic Department of Medicine, Royal Free Hospital, Pond Street, London, NW3 2QG

Accepted: 28 December 1984.
The haemoglobin concentration $(\mathrm{Hb})$ ranged from $7.1-11.1 \mathrm{~g} / \mathrm{dl}$ (mean $9.7 \mathrm{~g} / \mathrm{dl}$ ). The white cell count was normal. The blood films showed normochromic or slightly hypochromic red cells. In 6 cases marrow aspirates showed changes of 'chronic disease' (poor haemoglobinization of developing erythroblasts with normal iron stores). In one case there was a mild nonspecific increase in white cell precursors. In one case the aspirate was normal, and in another no aspirate was performed.

The plasma viscosity was over $2 \mathrm{cP}$ in all but one patient (normal 1.5-1.72). Plasma globulins were raised in all patients and electrophoresis showed elevated $\alpha_{2}$ globulins in 7 out of 8 cases. Two had very weak autoantibody titres to smooth muscle $(1: 10)$ and one a weak positive antinuclear antibody titre $(1: 10)$. Plasma alkaline phosphatase was moderately raised in all but one patient. Isoenzyme measurements were performed in 4 cases and the phosphatase found to be of liver origin. Rheumatoid factor was negative in the 7 patients tested. Four patients were subjected to temporal artery biopsy and 2 were positive for GCA.

The following were performed in the seven remaining patients: intravenous urography ( 3 cases), barium studies ( 4 cases), gastroscopy ( 3 cases), abdominal ultrasonography ( 3 cases), liver and bone radioisotope scan ( 5 cases), liver biopsy ( 4 cases), rectal biopsy ( 3 cases), lymph node and renal biopsy (each in one case). None of these investigations provided positive diagnostic information. Furthermore, all had fruitless searches for occult infection.

All 9 patients were considered sufficiently disabled to warrant a trial of corticosteroids and were given

(C) The Fellowship of Postgraduate Medicine, 1985 
Table I Clinical features and laboratory data at presentation

\begin{tabular}{|c|c|c|c|c|c|c|c|c|}
\hline \multirow{2}{*}{$\begin{array}{l}\begin{array}{l}\text { Age } \\
\text { (y) }\end{array} \\
76\end{array}$} & \multirow{2}{*}{$\frac{S e x}{F}$} & \multirow{2}{*}{$\begin{array}{c}\text { Symptoms } \\
\begin{array}{c}\text { Weight loss } \\
\text { Malaise }\end{array}\end{array}$} & \multicolumn{2}{|c|}{$\begin{array}{l}\text { Haemoglobin/Marrow } \\
\text { Pre-treatment }(\mathrm{g} / \mathrm{d})\end{array}$} & \multirow{2}{*}{$\begin{array}{c}\begin{array}{c}\text { Viscosity } \\
\text { (cP) }\end{array} \\
2.27\end{array}$} & \multicolumn{2}{|c|}{$\begin{array}{l}\text { Plasma globulin } \\
\text { (g/l, strip) }\end{array}$} & \multirow{2}{*}{$\begin{array}{c}\begin{array}{c}\text { Alk. phosphatase } \\
\text { (IU/l) }\end{array} \\
115\end{array}$} \\
\hline & & & 8.9 & $\begin{array}{l}\text { Chronic } \\
\text { disease }\end{array}$ & & 37 & $\left(\uparrow \alpha_{2}, \gamma\right)$ & \\
\hline 64 & $\mathbf{M}$ & $\begin{array}{c}\text { Fever } \\
\text { Weakness }\end{array}$ & 7.1 & $\begin{array}{l}\text { Chronic } \\
\text { disease }\end{array}$ & $1.73-1.91$ & 39 & $(\uparrow \gamma)$ & 191 \\
\hline 65 & $\mathbf{F}$ & $\begin{array}{c}\text { Anorexia } \\
\text { Weight loss } \\
\text { Fever }\end{array}$ & 10.8 & $\begin{array}{l}\text { Chronic } \\
\text { disease }\end{array}$ & 2.14 & 31 & $\left(\uparrow \alpha_{2}\right)$ & 115 \\
\hline 72 & $\mathbf{F}$ & $\begin{array}{l}\text { Dyspnoea } \\
\text { Anorexia }\end{array}$ & 8.3 & $\begin{array}{l}\text { Chronic } \\
\text { disease }\end{array}$ & 2.06 & 43 & $\left(\uparrow \alpha_{2}\right)$ & 109 \\
\hline 60 & $\mathbf{M}$ & $\begin{array}{c}\text { Anorexia } \\
\text { Weight loss } \\
\text { Tired }\end{array}$ & 9.2 & $\begin{array}{l}\text { Chronic } \\
\text { disease }\end{array}$ & 2.41 & 34 & $\left(\uparrow \alpha_{2}\right)$ & 132 \\
\hline 64 & $\mathbf{M}$ & $\begin{array}{c}\text { Fever } \\
\text { Tired } \\
\text { Anorexia }\end{array}$ & 9.7 & Normal & 2.10 & 33 & (not done) & 66 \\
\hline 77 & $\mathrm{~F}$ & Lassitude & 10.9 & Not done & 2.50 & 41 & $\left(\uparrow \alpha_{1}, \alpha_{2}\right)$ & 160 \\
\hline 65 & $\mathbf{M}$ & $\begin{array}{c}\text { Fever } \\
\text { Night } \\
\text { sweats }\end{array}$ & 11.1 & $\begin{array}{l}\text { Mild WBC } \\
\text { increase }\end{array}$ & 2.09 & 35 & $\left(\uparrow \alpha_{1}, \alpha_{2}\right)$ & 134 \\
\hline 72 & F & $\begin{array}{c}\text { Sub- } \\
\text { mandibular } \\
\text { swelling } \\
\text { Lassitude }\end{array}$ & 11.0 & $\begin{array}{l}\text { Chronic } \\
\text { disease }\end{array}$ & 2.13 & 33 & $\left(\uparrow \alpha_{2}\right)$ & 159 \\
\hline
\end{tabular}

The last 4 had temporal artery biopsy and the last 2 were positive for arteritis. Normal ranges: $\mathrm{Hb} 13.5-17.0$ in males and $11.5-15.5$ in females; globulins $15-30 \mathrm{~g} / \mathrm{dl}$; alkaline phosphatase 21-92 IU/l; Plasma viscosity $1.5-1.72 \mathrm{cP}$.

prednisolone $30-60 \mathrm{mg} /$ day initially. All were carefully followed, as inpatients initially, and laboratory data monitored.

\section{Results}

All patients experienced a marked subjective improvement within a few days of prednisolone therapy. The 4 who were pyrexial became afebrile within $24 \mathrm{~h}$.

One patient was sufficiently symptomatic from a low haemoglobin to warrant transfusion before starting prednisolone therapy. In this case the haemoglobin remained normal after transfusion. In those not transfused a rise in haemoglobin to within the normal range occurred within a few weeks. A swift fall of plasma viscosity to within or just above the normal range occurred in all cases (see Table II). Plasma globulins and liver function tests reverted to normal.

One patient with a strong family history of diabetes mellitus required treatment for this condition shortly after commencing prednisolone. He is now off prednisolone, and his diabetes controlled on chlorpropamide. No morbidity from corticosteroid therapy was seen in the remainder.
One patient died from a ruptured aortic aneurysm $6 y$ after starting prednisolone. The remainder are well at the time of writing (18 months to $7 \mathrm{y}$ after prednisolone commenced). Four are off treatment and 4 continue on a small daily dose of prednisolone $(10 \mathrm{mg}$ or less, see Table II).

We are only able to trace one other elderly patient who presented in a similar manner to those above, and in whom an unsuspected diagnosis came to light during a trial of steroid therapy. This patient had a renal carcinoma which was not identified on intravenous urography at the time of her initial investigations.

\section{Discussion}

Elderly patients frequently present with a variety of non-specific disabling symptoms and are found to have anaemia and a high ESR (or plasma viscosity). If physical examination is normal and simple investigations such as white cell count, urine and blood cultures, chest $\mathrm{X}$-ray, autoimmune and myeloma screens are all negative, an occult neoplasm may be sought. If no such neoplasm is found, a temporal artery biopsy should be performed even if the charac- 
Table II Follow up clinical data and response of anaemia and plasma viscosity to corticosteroids

\begin{tabular}{ccccc}
\hline Haemoglobin $(\mathrm{g} / \mathrm{dl})$ & Plasma viscosity $(\mathrm{cP})$ & $\begin{array}{c}\text { Duration of } \\
\text { follow up }\end{array}$ & $\begin{array}{c}\text { Duration on } \\
\text { prednisolone }\end{array}$ & $\begin{array}{c}\text { Dose at time of } \\
\text { of study }\end{array}$ \\
\hline 13.3 & 1.62 & Died $6 \frac{1}{2} \mathrm{y}$ & $5 \mathrm{y}$ & - \\
1.5 & $1 \frac{1}{2} \mathrm{y}$ & $1 \frac{1}{2} \mathrm{y}$ & $5 \mathrm{mg} / \mathrm{d}$ \\
14.2 & 1.55 & $4 \mathrm{y}$ & $4 \mathrm{y}$ & $3 \mathrm{mg} / \mathrm{d}$ \\
$\mathrm{Nil}$ & $\mathrm{Nil}$ \\
12.1 & 1.70 & $3 \mathrm{y}$ & $3 \mathrm{y}$ & $\mathrm{Nil}$ \\
13.7 & 1.70 & $2 \frac{1}{2} \mathrm{y}$ & $1 \frac{1}{2} \mathrm{y}$ & $\mathrm{Nil}$ \\
15.7 & 1.72 & $4 \frac{3}{4} \mathrm{y}$ & $1 \frac{1}{2} \mathrm{y}$ & $7.5 \mathrm{mg} / \mathrm{d}$ \\
\hline
\end{tabular}

teristic headaches and scalp tenderness are absent (Healey \& Wilske, 1971, 1980).

However, as Allsop \& Gallagher report (1981), a negative temporal artery biopsy does not exclude GCA and, if the biopsy is negative, the physician may be left with an ill elderly patient for whom further costly and uncomfortable investigations are unlikely to turn up an unsuspected treatable condition.

Between 1976 and 1982 we have seen 9 such patients. Two of them were found to have GCA despite the absence of characteristic symptoms of this disorder. On the presumption that the other 7 patients with identical clinical and laboratory presentations had a systemic illness allied to GCA, all were given a trial of corticosteroids. There was a marked subjective improvement in all patients. Objective evidence of improvement was pyrexia, if present, disappearing within $24 \mathrm{~h}$, a dramatic fall of the PV within a week, a return of liver function tests to normal, and a rise of the haemoglobin to within the normal range after a few weeks.

GCA often presents insidiously and atypically. Many authors (for example, Strachan et al., 1980) have described anaemia and weight loss as presenting

\section{References}

ALLSOP, C.J. \& GALlAGHER, P.J. (1981). Temporal artery biopsy in giant cell arteritis. American Journal of Surgical Pathology, 5, 317.

ESPOSITO, A.L. \& GLECKMAN, R.A. (1978). Fever of unknown origin in the elderly. Journal of the American Geriatric Society, 26, 498.

HEALEY, L.A. \& WILSKE, K.R. (1971). Anaemia as a presenting manifestation of giant cell arteritis. Arthritis and Rheumatism, 14, 27. features of GCA. This presentation may be associated with a raised alkaline phosphatase mimicking malignancy (Healey \& Wilske, 1980). Esposito \& Gleckman (1978) point out that pyrexia may be a presenting feature of GCA. Although only 2 of our 9 cases are biopsy proven, we suspect that all of our cases fall within the same spectrum of disease as GCA and polymyalgia rheumatica on the basis of similar laboratory data and corticosteroid responsiveness. Hume et al. (1973) report a similar group of 9 elderly patients with steroid-sensitive anaemias, 5 of whom probably had polymyalgia rheumatica, and draw attention to the rewarding long term response to treatment. However, in the absence of a positive temporal artery biopsy, a trial of corticosteroids should be conducted cautiously and the response of the haemoglobin and ESR should be carefully monitored.

\section{Acknowledgement}

We thank Professor P.J. Scheuer for reviewing the liver biopsies.
HEALEY, L.A. \& WILSKE, K.R. (1980). Presentation of occult giant cell arteritis. Arthritis and Rheumatism, 23, 641.

HUME, R., DAGG, J.H. \& GOLDBERG, A. (1973). Refractory anaemia with dysproteinaemia: long term therapy with low dose corticosteroids. Blood, 41, 27.

STRACHAN. R.W.. HOW, J. \& BEWSHER, P.D. (1980). Masked giant cell arteritis. Lancet, i, 194. 